\title{
The Death of God and Philosophy's Untimely Gospel
}

\section{Virgilio Aquino Rivas}

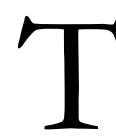
frue enough, not many of the human lot we know, not least of all those we may chance upon in life in an intricate tangle of modern social formations where individuals get to interface rather unreflectively most of the time, would be so generous as to bestow a casual interest in philosophy. Two thousand years ago, this kind of antipathy toward philosophy made its point well when a man named Socrates was condemned to death, proof rather of the unchanging isometrics of equivocation in the face of the compelling demands of justice and truth that Socrates exposed to be the skeleton in the cupboard of power, hiding under the façade of indestructibility. This pervasive practice would have by now covered an entire époque of Western intellectual tradition from the death of Socrates to the contemporary, disguised as unwavering love of everything that abounds in beauty and vitality, a determined search for the fundament that holds everything together under the condition that Man is free and that Life is precious as too rich and valuable for the taking.

Centuries on, Nietzsche, ventured to unsettle the complacency of his own generation, just about the challenge Socrates faced in his own time. Through the speeches of the ancient prophet Zarathustra Nietzsche brought around what seemed to be the dying cause of philosophy, of the love of everything that flowed with life, a creative wisdom of life but increasingly overshadowed by the technicity ${ }^{1}$ of modern times. Later, Heidegger would

\footnotetext{
1 We mean technicity in its traditional relation to metaphysics which in the process of "expressing and completing] itself as the project of calculative reason with a view to the mastery and possession of nature" becomes properly a domain of science, leaving behind its former schematic ambition of the totalization of humanity in terms of the medieval understanding of the ancient notion of phusis or nature via a reduction of beings to a system of moral or religious imperatives. See Bernard Stiegler, Technics and Time; The Fault of Epimethus, trans. by Richard Beardsworth and George Collins (Stanford, California: Stanford University Press, 19980, 10. Here also, technicity reveals the nature of our historical understanding of being, the 'being' that gets turned, twisted, and manipulated in the process of reduction and totalization. The understanding of this nature, however, in the sense of unmasking the de-naturing, or de-essencing it undergoes in our historical relation to being constitutes the essence of technicity itself as the Greeks understood it, that is, as a mode of revealing, disclosure or aletheia. Stiegler adds: "If modern technics nevertheless remains a mode of disclosure, it constitutes what is most properly to be thought. For it is through technics that the destiny of being unfolds, that is, technics is the history of being." Ibid. This consistently Heideggerian analytic of the beginnings of modern technicity is further summarized here by Stiegler: "At the beginning of its history philosophy separates techñe
} 


\section{PHILOSOPHY'S UNTIMELY GOSPEL}

bring to the attention of modern discourse the nature of technicity that had usurped the function of truth that Nietzsche exposed to be fundamentally refractory to the realization of human freedom.

\section{The Godless Age}

In the end, Nietzsche succumbed to a painful tragic dementia, died at his most irrational by any psychological standard. And for the untimely that he was in the eyes of his unsympathetic generation he was as much ugly as Socrates, his generation condemning the Socrates of their own time. But perhaps the more unseasonable philosophy is, the longer it survives. Zarathustra, the prophet, is even more untimely than his creator. The prophet after all was an antiquarian figure resurrected from the decrepit graves of more ancient past, but who as Nietzsche's brought-around creation has outlived the many ambivalent receptions of one of the most provocative literary figures ever created in Western intellectual tradition. Zarathustra the prophet is likened to Nietzsche himself - as the irreligious provocateur of nihilism, the high priest of the anarchistic church of the death of God, the instigator of totalitarian ideals vis-a-vis his alleged inspiration on Hitler's National Socialism, but also, an ardent believer in the noble virtues of humanity besieged by a sinister turn of civilization to reckless individualism, and a passionate defender of life as a free, continuous production. These ambivalent receptions of Zarathustra as of Nietzsche rather prove that the legacy of this particular intellectual tradition remains as rich as the life they embraced, rich in the sense of life's incredible openness to human endeavors, verdant of possibilities but only to the extent that God is dead. The death of God one way or another would beckon the era of human freedom, though possibilities of expanding the reaches of the human will beyond the modest aims of humanity are as great as the delicate hope that it would not abuse its discretion.

By a twist of more than a literary fate, Zarathustra, the prophet, was reintroduced to humanity by the tragic motivations of men vis-à-vis Nietzsche's battle against the decadence of his generation. It culminated in the ushering of a new civilization that prided itself of having exhausted the use for which Zarathustra's preaching of the promise of the death of God offered it a previously unimagined possibility. After casually appropriating the words of Zarathustra, this civilization had began to assume the place from where God had fled, the place of history. It propagated a new gospel for the new age, the gospel of the subject. This gospel endorsed the supreme virtue of individualism whose reputed ascendancy and predominance were made to match up to the omnipotence of God who, meanwhile, had decided to take refuge outside of

from episteme, a distinction that had not yet been made in Homeric times. The separation is determined by a political context, one in which the philosopher accuses the Sophist of instrumentalizing the logos as rhetoric and logography, that is, as both an instrument of power and a renunciation of knowledge. It is in the inheritance of this conflict-in which the philosophical episteme is pitched against the sophistic techñe, whereby all technical knowledge is devalued - that the essence of technical entities in general is conceived." Ibid, 1. 


\section{RIVAS 141}

history for fear of unthinkable deicide on the hands of the new idols. God did not die. He simply fled.

The new gospel replaced the previous hagiography that had wielded enormous moral authority over the destiny of humankind. It replaced the saints with men of brave unfailing hearts, more capable of transforming the world than were the martyrs of the preceding ages with their talk on salvation and the coming of the reign of God. These men almost by overnight became the new philosophers, artists, and saints (Nietzsche, 1983: 159) who were originally Zarathustra's preferred audience until these men finally frustrated him. ${ }^{2}$ It may be recalled that Zarathustra was last seen in action on his mission when he, frustrated with his higher men whom he said did not acquire the proper 'ear' to listen to him, decided to leave his cave where he used to intoxicate his audience with hymns for the future (Nietzsche, 1968:335). He left the cave, presumably, to refresh himself for another mission with a new audience. But the cave, which is getting more figuratively exhaustive of the sense for which the real world, our true world, stands, was preparing to host the new visitors in the guise of the triumphant men who plotted to take over the place of God. These men narrated their exploits culminating in the death of God. But they needed a lie-the lie that God is dead! - to cover up the truth that He was unharmed and had been in exile. After Zarathustra's speeches were displaced by the gospel of the 'subject', these men assumed themselves in the place of this 'subject', the subjectness that traded place with God.

It was at this point (and about the time when Heidegger attended Zarathustra's speeches via Nietzsche's philosophical corpus) when the German successor to Nietzsche offered a philosophical parallel of the death of God and the arrival of the new men:

Never can man put himself in the place of God, because the essence of man never reaches the essential realm belonging to God. On the contrary, compared with this impossibility something far more uncanny can happen....Thought metaphysically, the place that is peculiar to God is the place of the causative bringing about and preserving of whatever is, as something created. That place of God can remain empty. Instead of it, another, i.e. a place corresponding metaphysically, can loom on the horizon... [Rather] the place into which....willing enters is another realm belonging to

\footnotetext{
${ }^{2}$ In Zarathustra, Nietzsche referred to these types of men as higher men. For the exact context of its usage in Nietzsche's works, see Friedrich Nietzsche, "Schopenhauer as Educator," in Untimely Meditations, trans. by R.J. Hollingdale (Cambridge: Cambridge University Press, 1983), 159. In Schopenhauer as Educator, Nietzsche anticipated Zarathustra's frustrations with his chosen audience: "Where are we, scholars and unscholarly, high placed and low, to find the moral exemplars and models among our contemporaries, the visible epitome of morality for our time? . . . Never have moral educators been more needed, and never has it seemed less likely they would be found. Ibid., 132-133.
} 


\section{PHILOSOPHY'S UNTIMELY GOSPEL}

another grounding of what is, in its other Being. This other Being of what is, meanwhile - and this marks the beginning of modern metaphysics-has become subjectness. ${ }^{3}$

In the meantime, God spurned in his own dominion had just begun to wage a guerilla mission to take back his former territory. It was not God acting alone. His displacement has not in the least reduced His capacity to make a forcible comeback with what of the porous nature of history, its fundamental openness to the adventures of the human order, give and take the opportunities and the vagaries which influence the outcome of historical initiatives, especially, with a vision to totalize the world of which all known history has been revealed to be an easy captive. This is to say that God, though temporarily held in disrepute, had sufficient historical background, indeed, a mastery of general history to gather renewed strength, recovering and planning His return within the protected walls of human institutions $\mathrm{He}$ built to perpetuate His legacy - the ecclesiastical institutions of divine learning and experience, but more so, within the plastic dimension of humanity's conscience that He left totally scandalized by His defeat. God was not as deader as stiff. Had not the death of God paved way to multiple demigods battling it out for supremacy? Indeed, as Nietzsche emphasized, God is dead but it will take a long time to cast away his shadows. 4

Perhaps, alluding to the opportunity for human self-determination after God had fled, Nietzsche placed his hopes on the kind of wisdom that humanity had found in science but which in order to be determinative for humanity's god-less destiny must begin to be at last cheerful and gay while feeling at home finally in a world it could call its own. Nevertheless, while the shadows of God had not been totally cast away, it was the task of gay science to promote "a really scientific education" 5 that will teach us the-

New struggles. - After Buddha was dead, his shadow was still shown for centuries in a cave-a tremendous, gruesome shadow. God is dead; but given the way of men, there may still be caves for thousands of years in which his shadow will be shown.-And we-we still have to vanquish his shadow, too. ${ }^{6}$

\footnotetext{
${ }^{3}$ Martin Heidegger, Question Concerning Technology and Other Essays, trans. by William Lovitt (New York: Harper \& Row, Publishers, 1977), 100.

${ }^{4}$ Friedrich Nietzsche, Gay Science, trans. by Walter Kaufmann (New York: Vintage Books, 1974), 167.

5 A playful allusion to Nietzsche's words for Ralph Waldo Emerson whom he revered as a real mentor. Nietzsche was reported to have written about Emerson: "I do not know how much I would give if only I could bring it about, ex post facto, that such a glorious, great nature, rich in soul and spirit, might have gone through some strict discipline, a really scientific education. As it is, in Emerson we have lost a philosopher." Kaufmann in Nietzsche, Gay Science, 7.

${ }^{6}$ Ibid., section 108, 167.
} 


\section{RIVAS 143}

\section{Being- in- the- Draft}

For his own contribution to scientific education, it would take Heidegger to envision a being invested with 'primordial powers' to rescue the human community from a state of heightened desperation borne of the untimely flight of God and the arrival of the new ones. Mounting his own campaign to resurrect Zarathustra whose speeches he attended via Nietzsche, his true mentor, Heidegger exhorted Da-sein, presumably Zarathustra's successor in the age of the new idols, to start reclaiming these powers. Heidegger once alluded to "being in the draft of" a reference to the primordially creative link of the human being to the spirit of the times, that is, to the actual changing conditions of history. ${ }^{7}$ If only being could be rescued from the concealedness of things of which its customary understanding of itself and the awareness of its time and environment are standard learning drills that discourage unconcealing (or aletheia), the draft would have taught well this being the appropriate attitude toward the changing conditions of the time. To become a "being in the draft of," Heidegger instructed Da-sein to pay attention to the following:

As we are drawing toward what withdraws, we ourselves point toward it. We are who we are by pointing in that direction-not like an incidental adjunct but as follows: this "being in the draft of" is in itself an essential and therefore constant pointing toward what withdraws. To say "being in the draft of" is to say "pointing toward what withdraws". 8

To be in the draft of means to unconceal, to submit to aletheia the organized concealment of things which, as it tries to keep the human condition away from the possibility of self-awareness, extends all the worst the distance between the concealment of things and their unconcealment. As this distance extends, Man is made to distantiate also from himself and the human condition. To be 'in the draft of apropos this extending distance is therefore one of Da-sein's urgent tasks.

Meanwhile, even at the height of its most tremendous power, the power which technology exhibits as the great distancing lever, the draft seems to have been designed after all to capture an audience that can witness, in different modes of paying attention to the spirit of the times, the recoiling of technology from having anything to do with man. ${ }^{9}$ It would be fortunate for

7 Martin Heidegger, Basic Writings of Martin Heidegger, ed. by David Farrel Krell (London: Routledge, 1978), 375.

${ }^{8}$ Ibid.

9 That is, "the condition which makes authenticity and inauthenticity possible." This Heidegger assigned to "mineness" in which case "Dasein is an entity". Heidegger adds: "Dasein] exits in one or the other of these two modes, or else it is modally undifferentiated" 


\section{PHILOSOPHY'S UNTIMELY GOSPEL}

the entire cause of the human condition if it be witnessed by men who possessed of honorable intentions, among which is to alert mankind that a new religion - that of technocracy - was emerging. Unfortunately, in the time of Da-sein as of Heidegger, this recoiling, or in Heidegger's words, the entrappingwith-oblivion ${ }^{10}$ of technology had been witnessed by those with dark sinister intentions, among which was to intimidate God with just enough bluff as to force Him to pack his belongings and forsake the battlefield. That way there would be least bloodshed to make as otherwise would have been greatly expended in the wake of an absolute confrontation. As expected, these men were to become the harbingers of the new religion in which, as Nietzsche foresaw, God's shadows would be revealed.

A being that has understood itself well as a being in the draft of how things are concealed from it is indeed a being whose being-in-the-world can very well offer possibilities for self-creation and self-overcoming over the course of a lifetime. These possibilities will be the offshoots of the full uncovering of truth by way of "letting beings be the beings which they are and as they are."11 But it can only happen when beings have finally regained their primordial powers that had been divested of them by technology which in Heidegger's days had taken the place vacated by God. Technology had started to represent the boldness of the new idols that had won the first stage of the war against the old religion. Technology became the new religion, the secular religion of the post-metaphysical age. In the meantime, having disowned Zarathustra as their prophet, the new idols began to elevate themselves into the pantheon of the gods, seeking a repeat of the pagan days when gods, aspired for the approval of men. But, like the pagans, these idols were fated to be crushed out by shifting patterns of allegiances, fomenting civil wars driven by mutual paranoia, jealousy and suspicion, consuming themselves in a war of vanity, until a great leveling power that had silently monitored the developments from a distance unleashed its might. That 'power' unfortunately had the time to witness the draft for its own evil intention- promising a new and better order, but first, an order that is free of narrow-minded loyalties. Only a single loyalty was to make the desirable future within reach. That is loyalty to the Fubrer.

\section{God's Second Death}

When crises over history and its manifestations in the degree of concealment that things are made to assume erupt out of proportions, threatening not only beings themselves but the world in which they are beings to such an extent that beings are cut loose from their worlds and worlds fragment into ever more confused beings-without-worlds, calls for emancipation of being from concealment could very well become prey to rhetorical agenda. The

\footnotetext{
(Heidegger, Martin, Being and Time, trans. by John Macquarrie and Edward Robinson (Oxford: Basil Blackwell, 1967), 78.

${ }^{10}$ Heidegger, Question Concerning Technology, 43.

${ }^{11}$ Heidegger, Basic Writings, 127.
} 


\section{RIVAS 145}

rise of the Fubrer is an example of this proneness. In the hands of this great leveling power, being was forced to disengage from its own individual concerns so that a common destiny with other beings would soon be forged. This was done in stripping individual beings of their potentiality to understand their own selves - in Heidegger's words, their potentiality-for-Being, ${ }^{12}$ their awareness of the being as the beings that they are and as they are. Beings were cut loose from time, from history, from their own 'selves' as originally forming a link to time and history. This was the making of a utopia at its most brazen form. Beings became beings without worlds, without time, without history: supernatural selfless beings who were made to relinquish their self-concepts against which Zarathustra sharpened his speeches_-"He who does not believe in bimself always lies." 13 Meanwhile, the technological underpinning behind the success of this great leveling power was all the more so utilized in the service of the new religion. God had returned on earth, but under a new cloak. His subjectivity was resurrected beneath the cloak of technology. It was a cloak so huge and expansive that it threatened to conquer the planet with the force of willpower never before imagined of a god once famous for its vengefulness though restricted to local events like the God of the Jews in relation to the Jewish lot. In other words, the annihilation of the whole planet had never been real. ${ }^{14}$

From about the same period of the rise of the Fubrer to his downfall at the close of World War II, another idol was busy concentrating his power that harbored ambitions of rebuilding an empire from the ruins of the kingdom of God. ${ }^{15}$ The terror of the Soviet Fubrer was unleashed at a point when the death of God had gone past the period of high-strung desperation, which gave rise to Hitler in Germany, to a period of covert mourning, which gave form to the Soviet gulag. It was mourning for the unpreparedness of the earth to bury God. The immensity of His shadows required the constructions of more supplementary caves where they could be interred in addition to thousands formed over the ages in which God's shadows will be shown after His death. ${ }^{16}$ Nevertheless, these shadows were too ghastly for men tasked to bury Him. They feared burying Him.

Soon the shadows took it upon themselves to undertake their own burials, but in the souls of these men. God had departed for the second time; $\mathrm{He}$ had fled this time to the souls of the men who were led to believe they had murdered Him. It was guilt over which these men grieved later. And later, it

\footnotetext{
12 Heidegger, Being and Time, 318.

13 Nietzsche, "Of Immaculate Perception," in Thus Spoke Zarathustra. A Book for Everyone and No One, trans. by R.J. Hollingdale (New York: Penguin Books, 1969), 147.

${ }^{14}$ This threat can be more deadly: "The struggle for dominion over the earth is in its historical essence already the result of the fact that whatever is as such is appearing in the mode of the will to power without yet being recognized or without being understood at all as that will...With the beginning of the struggle for dominion over the earth, the age of subjectness is driving toward its consummation. To this completion belongs the fact that whatever is...is, after its fashion and in every respect, becoming certain and therefore also conscious of its own truth about itself." Heidegger, Question Concerning Technology and Other Essays, 101.

15 That is, the Soviet communist regime that replaced the tsarism in Russia.

${ }^{16}$ Nietzsche, Gay Science, 167.
} 


\section{PHILOSOPHY'S UNTIMELY GOSPEL}

was terror unleashed by guilt. Methodically, these men in whose souls God had taken refuge unloaded their guilt to innocent suffering civilians in whose souls the infinitely divisible shadows of God found new hosts. And the new hosts unloaded their guilt too, but for the indivisibility that this guilt had become, it became too humanly impossible to catch up. In the process they lost their memories of these shadows-all for the good of the shadows. Most of them had no recollection of the death of God. Indeed, having no recollection of evil at all, much less the evil-doer, meant that "from [that] very time it is against this wrath, and particularly against the wrath of those directly injured, that the evil-doer is carefully shielded and protected by the community."'17 But more than anything, the terror was designed to hide the fact that Man was coddling the divine. And by God's enormity which demanded countless light-proof detention camps to keep His multiple unaccounted shadows from escaping, we could imagine how immensely dark the terror was.

After the Second World War, a low intensity antagonism for the control of the planet took center stage. ${ }^{18}$ But another era of concealment took place in the aftermath of the fall of the Iron Curtain, this time with the full benefit of the situation in which concealedness is globally protected by the mighty survivors of the low intensity war which paved the way to new divisions of the world and new inevitable conflicts arising from new tactical concealments advanced by these survivors against one another. ${ }^{19}$ In this coming to presence of a new age, those beings cut from their worlds have their worlds somehow returned to them by some auspicious movements of the draft - that is, the relative progress of historical unconcealment despite the overriding technicity of power on the level of general history which thrives in truth concealment - that had, for instance, caused the dissolution of the Iron Curtain which symbolized the severity of the concealment it once perpetuated. But as already beings-without-worlds, some less fortunate would persist as most sternly resistant to adaptation after the fall of Concealment symbolized by the policy of isolation, thus the Iron Curtain moniker set up by the former Soviet Union. With too little preparation to welcome back their worlds in which as beings they originally were, they found their own worlds no longer the same. They found them ghastly and fearsome, uninhabitable. They barely recognized these worlds once accommodated them. They who have become most resistant to adaptation have become increasingly unaware, in fact, surprised that new worlds are emerging despite them. (This situation prompted efforts to unite the post-Cold War Europe, known today as the European Union). In proportion to their surprise, we were surprised by attacks of terror. The genocidal events that disturbed the moral conscience of

\footnotetext{
${ }^{17}$ Friedrich Nietzsche, Genealogy of Morals, trans. by Horace Barnett (New York: Dover Publications, Inc., 2003), 46.

18 That is, the low intensity conflict that described the US approach towards the Cold War with the former Soviet Union. This approach was designed to prevent mutual destruction of two nuclear capable nations which thrived in espionage, economic sabotages, etc. in lieu of the absolute option of mutual annihilation.

${ }^{19}$ The era of globalization that followed after the end of the Cold War.
} 
the new world after the fall of communism, and the rise of terror perpetuated by those extremely isolated if not most stunningly devastated, disillusioned and dispirited by the war of ideologies that defined the Cold War indicate that the end of Concealment had never gotten as much close to a real closure. The tension is now at a critical juncture: "the extremes appear" and are now vying for predominance. ${ }^{20}$ It could be the extension of the nihilism earlier detected by Nietzsche in his own time as "the decline and recession of the power of the spirit." 21 Extremes vying for predominance are proofs of the decline of the human spirit that has succumbed to a new form of desperation, and a recession of human powers that have yielded to the base instincts-the "wild, free, prowling" instincts of Man. ${ }^{22}$

\section{The Dangers of Subjectivity}

Out of the pressures of the overburdening nihilism of its own day, Dasein fell into the trap of the rhetoric of emancipating being from concealment. Heidegger's collaboration with the subjectivity that symbolized the hyperbolic ambition of the new age to conquer the planet so as to transform it into a better world proved the elusive nature of that trap. His Rectoral Address justified the choice of Da-sein whose essential Being-with-one-another ${ }^{23}$ would have to condone the rise of subjectivity if only to emphasize that beings must necessarily proceed from themselves in the midst of what had become of the essence-less foundation of things brought on by the death of God. From themselves means from within a compelling horizon of common subjectivity, which owing to its forcefulness would usurp the function of time as the true horizon of subjectivity in the sense of bounding subjectivity to the historical limits of the exercise of human will. Hence, the ahistoricality of timeusurpation by subjects assuming the function of temporality, culminating in a forcible assumption of the infinity that characterizes time. The infinity of time is such that it is revealed inherently without form, without positive identity, without a promise to offer - not least of all in the period of the death of God-except to intimate that Da-sein ought to weigh its choices more discreetly before making an irreversible leap. Paradoxically, however, it is to the infinity of that horizon (in the sense of the abstract character of time) that Da-sein authentically belongs, that is to say, Da-sein authentically belongs in the facelessness of its own future. Time holds no obligation to Da-sein, and Da-sein, in virtue of its mortal limitations, can take no bigger obligation (as to time) than it can make for 'itself. The relation between Da-sein and time, between 'being' and 'time' is thus one of tensional intimacy.

Earlier, the Fubrer underscored the dream of a self-less destiny, which means a destiny devoid of the human condition, of selves that were otherwise

${ }^{20}$ Friedrich Nietzsche, The Will to Power, trans. by Walter Kaufmann and R.J. Hollingdale (New York: Vintage Books, 1967), 11.

${ }^{21}$ Ibid., 17.

22 Nietzsche, The Genealogy of Morals, 57.

${ }^{23}$ Heidegger, Being and Time, 436. 


\section{PHILOSOPHY'S UNTIMELY GOSPEL}

made to operate outside time, beyond history, therefore, of selves that do not exist. ${ }^{24}$ They would be allowed to exist instead as specters. What is striking about this logic is that self-lessness is the key to gaining a desired self, its destiny in a self-less future. Nevertheless, while the destiny was just unfolding, humans needed a 'clutch' to hold on to something tightly, for the specters that they had become would have lost all sense of 'touch'. Hamlet had foreseen this: "[Our] time is out of joint." For an increasingly bewildered Da-sein, especially at a point where no being could have possessed the gift of absolute foresight of things to come, the horizon of the self gets discovered instead in 'resoluteness for definite possibilities." Once it chooses to understand itself as a being that knows itself as a resolute it-self, a self that can decide to make a leap, it is only then that being communes (not without a serious degree of selfdeception because it believes itself to be really in touch) with the external horizon, with the spirit of its time, the whispers and reverberations of its history. It would then be the perfect opportunity for the subject to control history, to control time, thereof making time 'finite', something 'ready-tohand', thus appropriatable vis-à-vis the infinity that escapes the appropriative grasp of the subject. Da-sein would have wished that this recourse to subjectivity was only a tentative recourse. Da-sein felt the dangers of subjectivity, especially when it was made to embrace the kind of witnessing of the draft that was too strong for it not to yield to, something that could immediately arouse suspicion because of the incredibility of its intensity an allusion to the sweeping triumph of the Nazi-subjectivity, with the Fubrer claiming the biggest part of a nation's subjectivity. ${ }^{25}$ But like any other being, Da-sein is prone to commit mistakes. Its collaboration with power was indeed an ugly choice. Zarathustra, who hoped that a fresh opportunity to speak again would come, was again frustrated, but for the lost of his most skilled, most able disciple whose mission bore resemblance to Zarathustra's. Zarathustra would have felt vindicated when this strange disciple of his from beyond his time crafted a beautifully written work on the question Who is Nietzsche's Zarathustra? - certainly, a tribute to the prophet who declared that "[he] has become ripe" and that "[his] time has come!"26 Zarathustra spoke these words when, in full sight of The Sign he was looking for, he saw that his "children were near", and also were the doves and the lion whose mighty roaring scared away his higher men approaching the cave where Zarathustra was resting. Earlier, he pitied his higher men whom he successfully intoxicated with his songs, his hymns for the coming future in which these men would be the creative rulers, but who in Zarathustra's words-

\footnotetext{
24 Nietzsche describes this escape into some beyond: "The end of the moral interpretation of the world, which no longer has any sanction after it has tried to escape into some beyond, leads to nihilism." Ibid., 7.

25 Heidegger, Basic Writings, 382.

${ }^{26}$ Nietzsche, Thus Spoke Zarathustra, 336.
} 
[Are] still sleeping....their dream still drinks at my intoxicated songs. Yet the ear that listens to me, the obeying ear, is missing from them. ${ }^{27}$

The Sign that Zarathustra saw, after his frustrations with his higher men, could have been the same sign that Da-sein must have wrongly interpreted. ${ }^{28}$ The roaring cries of the animals and the gliding of the airborne accompanied a crucial revelation - that instead of mourning for the lost of his men, he instead announced, gearing for another mission to go down to possibly a new batch of higher men-

'Pity! Pity for the Highermen Man!...'Very well! That-has had its time! 'My suffering and my pity-what of them! For do I aspire after my happiness? I aspire after my work! 29

Da-sein's fateful turn to subjectivity was a far cry from Zarathustra's resolve: the prophet loathed the messianic complex of looking after one's happiness as humanity's happiness. The prophet instead aspired after his work, but work as continuing self-creation and self-overcoming that put behind the frustrations of his mission as just another lesson learned. Unfortunately, when Zarathustra was gearing for a new mission World War II broke out. Incidentally, at about the period of the collapse of the great leveling power in the hands of the new claimant powers (the triumphant 'allies' of a new history of Being) whose bombs were sharper, their tanks more agile, their strategies more focused, Heidegger sought refuge in the golden lessons of the ancients. There he took to heart Zarathustra's last words- that he must aspire after his work — as he reviewed the still amazingly fresh pages that told of the virtues of the ancient polis, the resolution of its great men toward life and death, of the virtues of self-creation and self-overcoming, which Heidegger must have in mind when he once said, rather humbled by the more honest and restrained mission of Zarathustra, that "his writings were not works but paths."30 Certainly, he was not belying the prophet when he seemed unaffected by the admonition to 'aspire after the work'. The prophet must have meant setting out on a continuous pilgrimage whereupon each station his feet would land offered him a spanking new vigor to sharpen his speeches even

27 Nietzsche, ibid., 333.

28 As if anticipating Da-sein's difficulty in understanding the draft, Nietzsche's prognosis of nihilism told of the danger that accompanied the attempt to interpret its meaning for the present: "The end of the moral interpretation of the world, which no longer has any sanction after it has tried to escape into some beyond, leads to nibilism.. "Everything lacks meaning" (the untenability of one interpretation of the world, upon which a tremendous amount of energy has been lavished, awakens the suspicion that all interpretations of the world are false." Nietzsche, The Will to Power, 7.

${ }^{29}$ Nietzsche, Thus Spoke Zarathustra, 336.

30 At his old age, Heidegger is said to have claimed that "his writings were 'not works but paths"' - a reference to Da-sein's best possible exercise of transcendence, as a wayfarer, or a pilgrim in search of its destiny, or a shepherd that looks after its destiny. See Moran David, Introduction to Phenomenology (London: Routledge, 2000), 219. 
better, to convey more untimely words to men. In short, Heidegger's 'paths' were Zarathustra's 'works'. Nevertheless, it was a reformed Da-sein that took the prophet to heart.

\section{The Implosion of Beings in the New Age of Concealment}

Over the last 50 years or so after Da-sein witnessed the horrors of the last world war, there has never been a point in which humanity cared to askwhat had happened to beings that were cut loose from their worlds? And also- what about those worlds that had fallen apart but revived piece by piece in beings-without-worlds? Are we not these same beings that were torn apart from our world, and most of all, from our very own selves? Are we not the beings that, separated from time long ago, pretend we are still in control but just too absorbed in our vacant selves that we do not have much space in 'us' to accommodate the question-what happened to those beings that we were? Are we not these same beings that were and are now still made to occupy the place outside history, outside time? Descartes would have had a better opportunity to doubt if beings really exist.

Incidentally, in this global age, 'worlds' have been continually differentiating, brought on by the diversification of experiences created by a confluence of worlds in an active form of human commerce that has never been so extensive and penetrating as it is today, which may be discerned as positive for the task of aletheia or unconcealment: more worlds are now at the disposal of beings to be in. More worlds mean more opportunities for unraveling horizons, learning new and better tools of unconcealment. But also, unfortunately, opportunities for concealment to disguise itself as unconcealment in the liberal effusions of worlds in which beings can be beings.

While 'primordial worlds' have been continually torn apart to give way to a plurality of worlds in which we can be beings - the assumption is that with more worlds there will be expanded solidarities to promote and develop in the hope of forging a universal humanity-it is also certain that the flurry of worlds offering themselves for creative 'dwelling' or happening', places untold burdens on beings who, before the aggressive turn of globalization, had been outstripped already of their original there-ness, of worlds deprived of them. Heidegger identified this particular setting, for instance, as the period when 'housing shortage' was a national issue, fomenting migrations. ${ }^{31} \mathrm{He}$ did not, however, survive long enough to witness how 'housing shortage' as an issue had been overtaken by the concern over the volatility of the very ground on which houses could be built, namely, the world in which beings with housing problems could be the beings that they are and as they are in relation to their primordial worlds now threatened by globalization in the sense we have spoken above. Still, Heidegger saw to it that even without the benefit of the housing issue-

${ }^{31}$ Martin Heidegger, Poetry, Language, Thought, trans. by Albert Hofstadter (New York: Harper \& Row, Publishers, 1971), 161. 
The real dwelling plight lies in this, that mortals ever search anew for the nature of dwelling, that they must ever learn to dwell. . .

But how else can mortals answer this summons than by trying on their part, on their own, to bring dwelling to the fullness of its nature? This they accomplish when they build out of dwelling, and think for the sake of dwelling. ${ }^{32}$

Paradoxically enough, the argument for dwelling's sake anticipated the proper attitude towards a situation in which being is detached from its original world in that the only appropriate way is to "bring dwelling to the fullness of its nature" wherever being is thrown (again) by some chance or necessity. Nevertheless, globalization has put more currency on 'dwelling' in such a manner as to "think for the sake of dwelling" risks a regression into inauthenticity, into a mode of being oblivious to its primordial world, to its historicity.

At any rate, being's sense of there-ness expands. But there-ness can unduly expand into a multiplicity of opportunities for self-creation and selfovercoming but on a scale of individual unconcealments that is at risk of tipping into a complex mass of individual approaches and strategies to deal with beings and with time as well, thereby rendering the process of aletheia too complicated. Globalization feeds on this confusion. It demands that we outstrip ourselves of the original worlds in which we are beings so that we can commune with other beings whose original there-ness must also be necessarily outstripped from them. In this supposedly healthy exchange of worlds, beings are expected to share their experiences of concealment and unconcealment for others to share their own in an open, transparent commerce of truths. In the time of globalizing worlds and beings as well, we are encouraged to discourse less of being-in-the-world, but more on 'happening,' on the 'dwelling' of being. Without belying the critical import of these modes of being-ness as they make us all the more aware of the dangers of de-worlding in and through the implosion of subjectivities, capable of dwelling in many worlds, the new focus has also unwittingly given a name to a new process of divesting beings of their original worlds and has weighed in a complicating process to aletheia in proportion to the increasingly complicating mode of life that we are forced to bear today in the continuing age of the death of God. Certainly, our time has become 'more problematic', which is the most practical expression we can make of the actual and objective reality that nihilism has borne on us. Da-sein, the particular being-in the-world has lost its appeal in the new age, in short. Dasein is replaced by the cosmopolitan dwelling. Correspondingly, and this is true of the current hype on Heideggerianism, to speak of Da-sein today is to speak unfashionably of philosophy. 


\section{PHILOSOPHY'S UNTIMELY GOSPEL}

\section{The Task of Philosophy Today}

It is perhaps by looking at the mirror of our own time that philosophy can refresh its learning in untimeliness, but untimeliness not as going against time as the infinite horizon of being-ness, an infinite that resists the finitude that takes hold of time, making time subservient to instrumental ends. All the admonitions to infinity (inasmuch as they are 'untimely') - the struggle for justice, eudemonia, among others - are all reflected in the mirror of an evolving history which, however, get easily confused with immediate terms of human happiness, terms which lend themselves to opportunities for gratifying finite human needs. It is this finitude that the untimeliness of Socrates, Nietzsche, and Heidegger went against and proposed to destroy to give time the opportunity it deserves, to be at itself, at its infinite non-obligatory nature vis-àvis its relation to being. The finitude of time takes hold of being in the same manner as the subject takes hold of its destiny, which, by the way, can only craft a destiny in terms of being with others, hence, the subject taking hold of the destiny of beings. Indeed, the untimeliness that Socrates, Nietzsche, and Heidegger promoted is paradoxical at the very core: the untimeliness that alone can give time the time it deserves, namely, the time to give being its due, to receive time in its infinity, opposite the taking of time in its finite modality. This infinity is reflected in the mirror of our time, yet something we still cannot recognize.

But, looking at the mirror of our own time, philosophy might begin to refresh how it started as a fundamental question of justice in the human community that inspired the mission of Socrates. After a long time it got itself a more relevant question-of how to live a full life amidst the destruction of values that defined the modern epoch against which Zarathustra shied his untimely words. Decades forward, the question would be that of technologyhow to reinvent it with enduring human purposes that celebrate the best and the noble in Da-sein. ${ }^{33}$

As it looks in the mirror of the present time, philosophy sees its face getting older and older since the death of Socrates. The wrinkles, however, are proofs of an interruption in producing untimely messages anymore than its

33 Heidegger's essay The Question Concerning Technology summarizes the possibility of reinventing technology with human purposes. He traced the origin of technology to the ancient Greek understanding of techñe which originally meant, in Heidegger's words, as "that revealing that brings forth truth into the splendor of radiant appearing." (34). Previously attached to creative or artistic endeavors, techñe belonged within poiésis and for some time art started to bear the name techñe. Modern-day technology threatens to consign "all revealing" to a sort of frenzied ordering which "demands that nature be orderable as standing-reserve" (Ibid., 23) in which possibilities for "[entering] into a more original revealing and hence to experience the call of a more primal trutb" (Ibid., 28) could be denied to Man. Nevertheless, technology may still offer possibilities for reinvesting it with human purposes that had started its original course in the realm of the arts. As Heidegger says - the "coming to presence of technology harbors in itself what we least suspect, the possible arising of the saving power" (Ibid., 32). The saving power can best reveal itself to us only if "we pay heed to the coming to presence of technology" from its origin in creative arts (Ibid.). 
continuing to stay in the business for more than two thousand years would have anything definite to say about how old its face has become. If it is to regain itself, philosophy would have Nietzsche and Heidegger as its most dependable models of untimeliness. If to regain the freshness of philosophy is to be thoroughly unseasonable, certainly the recipes for untimeliness are no longer a secret. Nietzsche and Heidegger are the most untimely of the preachers of the last 150 years. Suffice it to say that a completely untimely philosophy must be thoroughly ugly and proud. If it can see in its face the face of Socrates, there philosophy has properly regained itself. Perhaps, both Nietzsche and Heidegger saw Plato's Socrates in the mirror of their own days; each wanting to contribute to untimeliness. With Zarathustra and Da-sein, they became even prouder, uglier.

Institute of Social History, Polytechnic University of the Philippines, Philippines

\section{References}

Brickhouse, Thomas C. and Smith, Nicholas D, Plato's Socrates (New York: Oxford University Press, 1994).

Heidegger, Martin, Basic Writings of Martin Heidegger, ed. by David Farrel Krell. (London: Routledge, 1978). , Being and Time, trans. by. John Macquarrie and Edward Robinson (Oxford: Basil Blackwell, 1967). Nietzsche, Volume Two: The Eternal Recurrence of the Same, ed. by and translated by David F. Krell (New York: Harper \& Row Publishers, Inc.,1982). Poetry, Language, Thought, trans. by Albert Hofstadter (New York: Harper \& Row, Publishers, 1971). Question Concerning Technology and Other Essay, trans. by. William Lovitt (New York: Harper \& Row, Publishers, 1977).

Curd, Patricia ed., A Presocratic Reader. Selected Fragments and Testimonia, trans. by Richard McKirahan (Indianapolis: Hackett Publishing Company, Inc., 1995).

Moran, David, Introduction to Phenomenology (London: Routledge, 2000).

Nehamas, Alexander, Virtues of Authenticity (Princeton: Princeton University Press, 1999).

Nietzsche, Friedrich, Basic Writings of Friedrich Nietssche, trans. by. Walter Kaufmann (New York: The Modern Library, 1968). , Gay Science, trans. by. Walter Kaufmann (New York: Vintage Books, 1974). , Genealogy of Morals, trans. by Horace Barnett (New York: Dover Publications, Inc., 2003).

Thus Spoke Zarathustra. A Book for Everyone and No One, trans.

by R.J. Hollingdale (New York: Penguin Books, 1969). Untimely Meditations, trans. by. R.J. Hollingdale (Cambridge: Cambridge University Press, 1983). 


\section{PHILOSOPHY'S UNTIMELY GOSPEL}

Will to Power. trans. by. Walter Kaufmann and R.J. Hollingdale (New York: Vintage Books, 1967).

Plato, "Crito," in The Norton Book of Classical Literature, ed. by Bernard Knox (New York: W.W. Norton and Company, 1993).

Schrift, Alan, Nietzsche and the Question of Interpretation: Between Hermeneutics and Deconstruction (New York: Routledge, 1990).

Smith, Gregory B. Nietzsche, Heidegger and the Transition to Postmodernity. (Chicago: University of Chicago Press, 1996).

Vlastos, Gregory, Socrates: Ironist and Moral Philosopher (Cambridge: Cambridge University Press, 1991). 